UNITED STATES

DEPARTMENT OF THE INTERIOR

GEOLOGICAL SURVEY

\title{
FLOODFLOW CHARACTERISTICS OF ARKANSAS RIVER \\ AT INTERSTATE HIGHWAY 540 \\ AT VAN BUREN, ARKANSAS
}

By

R. C. Christensen and R. C. Gilstrap

Prepared in cooperation with the

ARKANSAS STATE HIGHWAY COMMISSION

Open-file report

Little Rock, Arkansas

1965 


\title{
UNITED STATESS \\ DEPARTMENT OF THE INTERIOR \\ GEOLOGICAI SURVEY
}

\section{FLOODFLOW CHARACTERISTICS OF ARKANSAS RIVER \\ AT INTERSTATE HIGHWAY 540 \\ AT VAN BUREN, ARKANSAS}

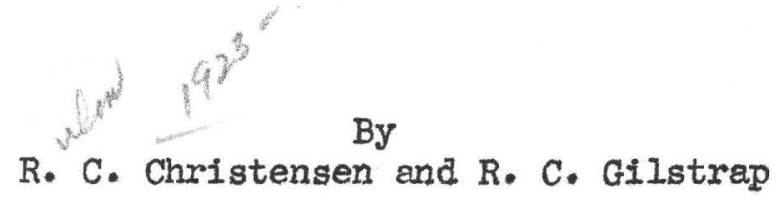

Prepared in cooperation with the

ARKANSAS STATE HIGHWAY COMMISSION

\author{
Open-file report \\ Little Rock, Arkansas \\ 1965
}


Introduction

Description of area.

Magnitude and frequency of floods

History and development.

Frequency curves.

Relation of elevation to discharge.

Distribution of flow

50-yeax flood.

Maximum flood of record.

Maximum elevation of water surface above constriction

Comparison of present bridge openings.

Summary

Data available

\section{SUPPLEMENT I}

Introduction.

Modified maximum flood of record

Recurrence interval of modified flood

Relation of elevation to discharge

Distribution of flow

\section{SUPPLEMENT II}

Introduction

Distribution of flow. 


\section{FIGURES}

Page

Figure 1. Location map

2. Flood-frequency curves_.......................... 14

3. Relation of elevation to discharge............ 15

4. Valley cross section and flow distribution

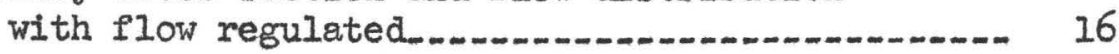

5. Valley cross section and flow distribution for 1943 flood..... 17

6. Valley cross section and flow distribution for modified maximum flood of record........ 21

7. Valley cross section and flow distribution for modified maximum flood of record for revised bridge openings 25 


\section{FLOODFLOW CHARACTERISTICS OF ARKANSAS RIVER \\ AT INTERSTATE HIGHWAY 540 \\ AT VAN BUREN, ARKANSAS}

\section{INTRODUCTION}

The Arkansas Highway Department proposes to construct a new highway across the Arkansas River three quarters of a mile downstream from the present crossing of U.S. Highways 64 and 71 at Van Buren. The new crossing will be a part of Interstate Highway 540 , which vill form a connecting link between Interstate Highway 40 north of the Arkansas River and State Highway 22 in Fort Smith south of the River.

The Arkansas Highway Department requested the U.S. Geological Survey to analyze the floodflow characteristics of the Arkansas River at the proposed Interstate Highway 540 crossing, to provide information which will assist them in determining the most feasible type and arrangement of embankment and waterway openings consistent with economic and engineering principles of highway-structure design. The Department has presented for an analysis, a main-channel opening and a relief opening on the right (west) flood plain.

This report was prepared under the provisions of the cooperative agreement between the Arkansas State Highway Commission and the Geological Survey and contains information for the particular site on the Arkansas River to show: (1) magnitude and frequency of floods; (2) relation of water-surface elevation to discharge; (3) distribution of flow in the approach channel and through the proposed bridge 
openings for the 50-year flood and the maximum flood of record;

(4) maximum elevation of water surface above constriction; and

(5) summary of floodflow characteristics.

All elevations given in this report are to highway datum, which is mean sea level.

\section{DESCRIPTION OF AREA}

The Interstate Highway 540 will cross the Arkansas River in an expanding reach of channel. The river begins to expand at a railroad embankment $1 \frac{1}{4}$ miles upstream and continues to expand through the existing highway bridge and on downstream from the proposed crossing. General features at the site are shown on the location map, figure 1.

The river consists of a deep main channel situated near the left edge of the flood plain and a wide expanding overflow section on the right bank. The flood plain is interwoven with cultivated fields and wooded areas. The area in the vicinity of the proposed relief bridge consists mainly of cultivated fields. During extreme floods the river, at the site, is about $1 \frac{1}{2}$ miles wide.

The proposed highway crosses the main channel in a normal direction; but, because of the expanding right flood plain, the proposed relief bridge and embankment runs at a skew of about 32 degrees from the normal to the direction of flow over the flood plain.

The drainage area above this crossing is 150,484 square miles, of which about 128,243 square miles contribute directly to surface runoff. 
MAGNITUDE AND FREQUENCY OF FLOODS

History and Development

According to records collected at gages on the Arkansas River at Fort Smith and Van Buren, the maximum stage known since at least 1833 occurred on April 16, 1945, at an elevation of 410.46 feet at the Van Buren gage, or about 409.8 feet at the proposed bridge site. The maximum discharge known since at least 1833 occurred on May 12, 1943, with a peak of 850,000 cfs (cubic feet per second). The same discharge would have occurred at the site. During the 1943 flood, the river levees failed in the vicinity of Van Buren and downstream, resulting in a lower stage than was experienced in the 1945 flood with a peak flow of $650,000 \mathrm{cfs}$. The levees were rebuilt after the 1943 flood and have contained all floods since that time.

Through the development of a comprehensive reservoir system, the flood potential of the Arkansas River at the site is being substantially reduced. Since the maximum discharge of record occurred in May 1943, several flood-control reservoirs have been built on tributaries of the Arkansas River that contribute to flooding at the site. Other reservoirs are nearing completion and will be ready for flood-control storage in about 2 years. With the completion of these reservoirs, all major tributaries of the Arkansas River will be controlled. Listed in downstream order in the following table are the principal flood-control reservoirs in operation or under construction, the streams on which they are located, and their flood-control storage capacities. 


\begin{tabular}{|c|c|c|}
\hline Reservoir & Stream & $\begin{array}{l}\text { Flood-control storage } \\
\text { (acre-feet) }\end{array}$ \\
\hline Keystone & Arkansas River & $1,464,000$ \\
\hline Heyburn & Polecat Creek & 138,800 \\
\hline Oologah $1 /$ & Verdigris River & 963,000 \\
\hline Lake O'The Cherokees & Grand (Neosho) River & 525,000 \\
\hline Markham Ferry & Grand River & 233,000 \\
\hline Fort Gibson & Grand River & 918,800 \\
\hline Tenkiller Ferry & Illinois River & 602,300 \\
\hline Eufaula & Canadian River & $1,470,000$ \\
\hline Wister & Poteau River & 399,600 \\
\hline
\end{tabular}

\section{Frequency Curves}

Two frequency curves, one for unregulated flows and one for regulated flows, based on records collected at the Van Buren gage are presented in figure 2. Discharge at the proposed site is equivalent to that at the gage.

The frequency curve based on unregulated flows was determined from the report, "Floods in Arkansas, Magnitude and Frequency."

The frequency curve based on flows regulated by the reservoirs listed in the preceding section, "History and Development," was prepared by the Corps of Engineers. From this curve, the discharge that may be expected to be equaled or exceeded on the average of once in 50 years is 500,000 cfs; hereafter refexred to as the 50-year flood. 
RELATION OF ELEVATION TO DISCHARGE

The relation of elevation to discharge (stage-discharge relation) is based on current-meter measurements below $611,000 \mathrm{cfs}$ and extended to $850,000 \mathrm{cfs}$ by logarithmic plotting. The current-meter measurements were made at the gaging station, "Arkansas River at Van Buren," located three quarters of a mile upstream. The discharge at the proposed highway crossing is considered equivalent to that at the gage. The elevation (stage) at the gaging station was reduced by the amount of fall in water surface to the site, which is about 0.7 foot during flood stage.

The plots of all the discharge measurements made above flood stage since 1943 show considerable shifting in the stage-discharge relation, due mostly to rate of change in stage and to changes in the sand-bed channel. Enveloping curves indicate a maximum change in stage of 3 feet for the same discharge.

The relation of elevation to discharge was developed to give the maximum discharge for a given elevation; or, in other words, the enveloping curve drawn through the discharge measurements plotting to the extreme right was used for the stage-discharge relation at the site. This relationship will give the highest mean velocities that will occur for a given discharge. The relation of elevation to discharge is show by the rating curve in figure 3. From this figure, the stage corresponding to the 50 -year flood of 500,000 cfs is 404.9 feet. Iikewise, under present channel conditions, the elevation corresponding to a discharge equal to the 1943 flood (850,000 cfs) is 412.9 feet. 
The Corps of Engineers has prepared an estimated profile for a regulated 50-year flood with all planned locks and dams in place downstream from the proposed crossing. On the basis of this profile, the elevation-discharge relation at high stages will not be significantly affected by presently planned river development.

\section{DISTRIBUTION OF FLOW}

The distribution of flow in the approach channel has been computed for a discharge equal to the 50-year flood of 500,000 cfs and for a discharge of $850,000 \mathrm{cfs}$, which is equal to the maximum experienced flood of record. The distribution of each flood across the approach channel was computed by the relative-conveyance method as outlined in previous reports.

The discharge through individual bridges of a multiple-opening river crossing is proportionate to the effective area of the openings. When there is nonuniformity in the approach, due to shape or roughness, the discharge must be adjusted for the influence of channelresistance characteristics on flow distribution. Nonuniform conditions exist in the approach to the proposed bridge openings, and. the distribution of flow for each flood given above has been computed accordingly.

The levee on the left bank is offset from the general levee alignment upstream and downstream from the proposed main-channel bridge. It is believed that the area under about 500 feet of the bridge in this levee offset would be ineffective in passing floodflows. (See figures 1, 4, and 5.) 
50-Year Flood

In figure 4, the water-surface elevations for the 50-year flood, the 1943 flood for present channel conditions, and the proposed waterway openings are shown on the profile of the valley along the proposed centerline.

The distribution of the 50-year flood (500,000 cfs at elevation of 404.9 feet) in the approach channel and through the proposed bridge openings is also shown in figure 4. The hydraulic data for the flow through the openings are presented in the following table:

$\begin{array}{llllc}\text { Bridge opening } & \frac{\text { Discharge }}{n n n n} & \text { Area } & & \text { Mean velocity } \\ \text { Main channel } & 480,000 \mathrm{cfs} & 63,913 \mathrm{sq} \mathrm{ft} & 7.5 \mathrm{fps} \\ \text { Relief } & 20,000 \mathrm{cfs} & 4,913 \mathrm{sq} \mathrm{ft} & 4.1 \mathrm{fps}\end{array}$

The division of flow will occur between stations $511+20$ and $517+00$, depending on the elevation at which the 50-year flood occurs. At the minimum elevation of 404.9 feet, a small ridge which runs parallel to the direction of flow will separate the approaching flow at station $511+20$. At higher elevations, the division of flow will occur about midway between the proposed bridge openings.

\section{Maximum Flood of Record}

The water-surface elevation for a discharge equal to the 1943 flood and the proposed waterway openings are shown on the valley cross section along the proposed centerline in figure 5. The elevation of 412.9 feet represents the minimum stage at which a discharge of $850,000 \mathrm{cfs}$ would occur under present channel conditions. 
The distribution of the 1943 flood $(850,000$ cfs at 412.9 feet) in the approach channel and through the proposed bridge openings is also shown in figure 5. The hydraulic data for the flow through the openings are presented in the following table:

\begin{tabular}{lcccc} 
Bridge opening & Discharge & & Area & Mean velocity \\
\cline { 2 - 3 } Main channel & $778,000 \mathrm{cfs}$ & & $84,221 \mathrm{sq} \mathrm{ft}$ & $9.2 \mathrm{fps}$ \\
Relief & $72,000 \mathrm{cfs}$ & $12,189 \mathrm{sq} \mathrm{ft}$ & $5.9 \mathrm{fps}$
\end{tabular}

The division of flow will occur near the relief opening at about station $504+00$.

\section{MAXIMUM ELEVATION OF WATER SURFACE ABOVE CONSTRICTION}

The maximum elevation of water surface along the upstream side of the proposed road embankment outside of the drawdown zone is principally dependent upon: (I) the maximum probable water-surface elevation at the downstream side of the embankment; (2) the normal friction loss between the beginning of the drawdown above the bridge opening and the downstream side of the embankment; and (3) the increase in elevation above the normal elevation in the unconstricted channel, which is commonly known as backwater.

The stage-discharge relation at the site is unstable. As explained in the section, "Relation of Elevation to Discharge," the change in stage for a given discharge can be as much as 3 feet. Therefore, the 50-year flood and the 1943 flood could occur at elevations as high as 407.9 and 415.9 feet, respectively, at the downstream side of the road embankment. 
The maximum water-surface elevation on the upstream side of the embankment will occur at the point of division of flow between the bridge openings. The increase in water-surface elevation that can be expected from the 50-year flood and the 1943 flood will be about 1.3 and 1.5 feet, respectively.

From the information given above, the maximum elevation of the water surface upstream from the proposed constriction for the 50-year flood and the 1943 flood will be about 409.2 and 417.4 feet, respectively.

\section{COMPARISON OF PRESENT BRIDGE OPENINGS}

The present crossing at the gaging station three quarters of a mile upstream, on U.S. Highways 64 and 71 , has a main-channel opening and a relief opening on the right flood plain. A discharge measurement of 476,000 cfs ( 5 percent less than the 50-year flood) was made May 27, 1957, by engineers of the Geological Survey. Hydraulic data from this measurement are shown in the following table:

\begin{tabular}{|c|c|c|c|}
\hline Bridge opening & Discharge & Area & Mean velocity \\
\hline Main channel & 443,000 cfs & $57,710 \mathrm{sq} \mathrm{ft}$ & 7.68 fps \\
\hline Relief & 33,000 cfs & $17,640 \mathrm{sq}$ ft & $1.87 \mathrm{fps}$ \\
\hline
\end{tabular}

Maximum point velocities found in the main-channel opening and the relief opening were 11.91 and 7.86 feet per second, respectively. 


\section{SUMMARY}

The floodflow characteristics of the Arkansas River at the crossing of Interstate Highway 540 are summarized as follows:

1. The flood potential is being greatly reduced by floodcontrol storage in upstream reservoirs.

2. The maximum discharge known since at least 1833 occurred on May 12, 1943, (peak discharge, $850,000 \mathrm{cfs}$ ) and reached an elevation of 410.36 feet at the Van Buren gage, or about 409.7 feet in the unrestricted channel at the proposed highway crossing. Under present channel conditions, a flood of equal magnitude would reach an elevation of at least 412.9 feet on the downstream side of the proposed road embankment. The constriction of flow caused by the embankment and bridges would increase the elevation of the water surface at the point of division of flow between the bridge openings to at least 414.4 feet.

3. The maximum stage known since at least 1833 occurred on April 16, 1945, with a peak elevation of 410.46 feet at the Van Buren gage, or about 409.8 feet in the unconstricted channel at the site.

4. For flows regulated by reservoirs, the 50-year discharge (that which may be expected to be equaled or exceeded on the average of once in 50 years) is $500,000 \mathrm{cfs}$ and would reach an elevation of at least 404.9 feet at the downstream side of the proposed road embankment. The constriction of flow caused by the embankment and bridges would increase the elevation of the water surface at the point of division of flow between the bridge openings to at least 406.2 feet. 
2. The Corps of Engineers furnished a flood-frequency curve for the Arkansas River at Van Buren for flows regulated by all authorized reservoirs; an estimated profile for a regulated 50-year flood (500,000 cfs) with all planned locks and dams in place downstream from the proposed crossing; a high-water elevation for the flood of May 28, 1957, at river mile 349.3; and an aerial mosaic of the proposed crossing.

3. Stage records collected by the Weather Bureau for Arkansas River at Fort Smith, Ark., 1879 to December 31, 1955.

4. Stage and discharge records collected by the Geological Survey for Arkansas River at Van Buren, Ark., October 1927 to date. The report, "Floods in Arkansas, Magnitude and Frequency." An engineer of the Geological Survey visited the site and selected appropriate channel-roughness coefficients and took stereo pictures of the important features of the area.

Base data and computations used in the preparation of this report are available in the files of the Geological Survey, Little Rock, Arkansas. 
Figurel. Location map, Arkansas Piver at Van Buren, Arkansas.

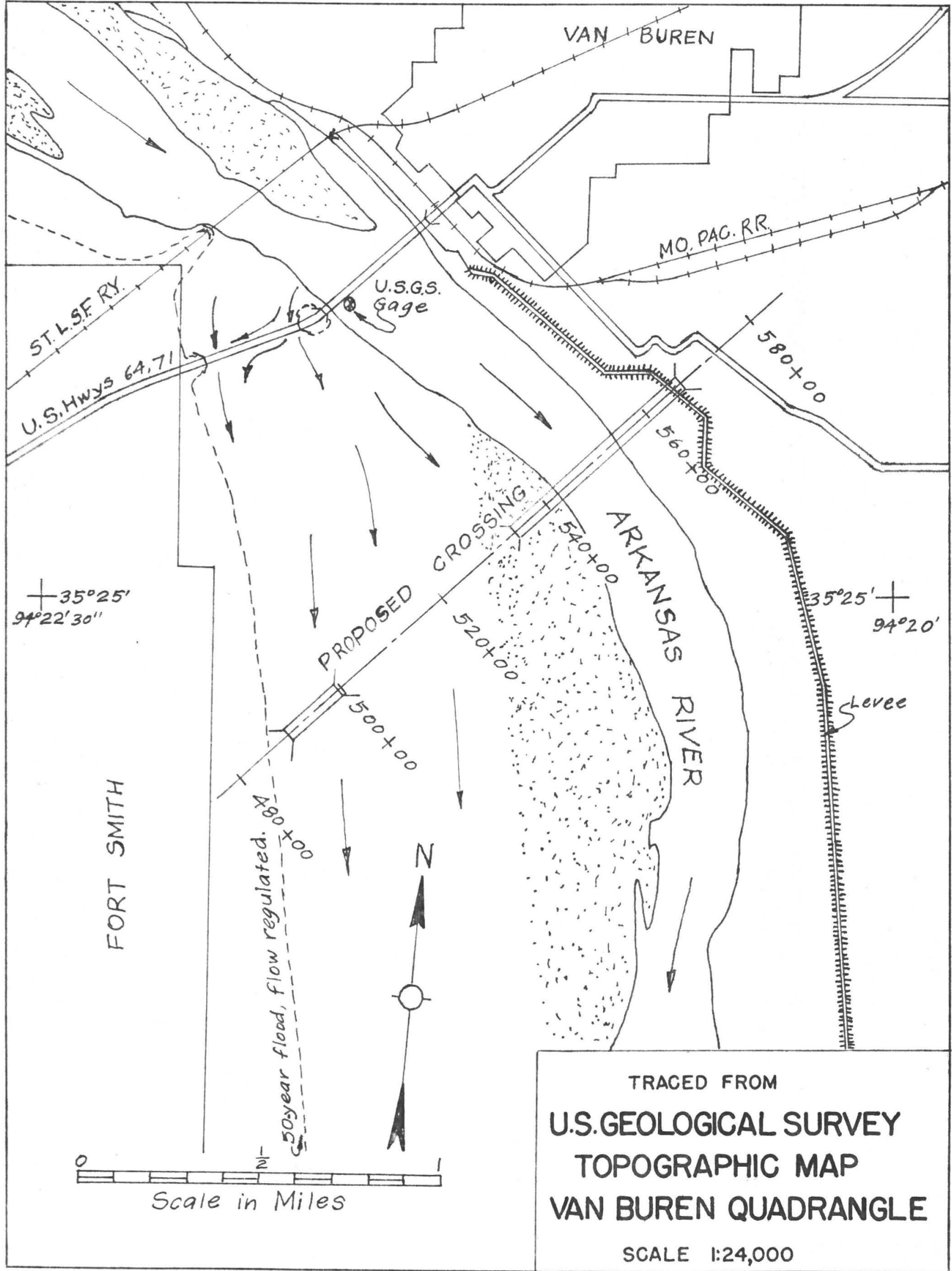




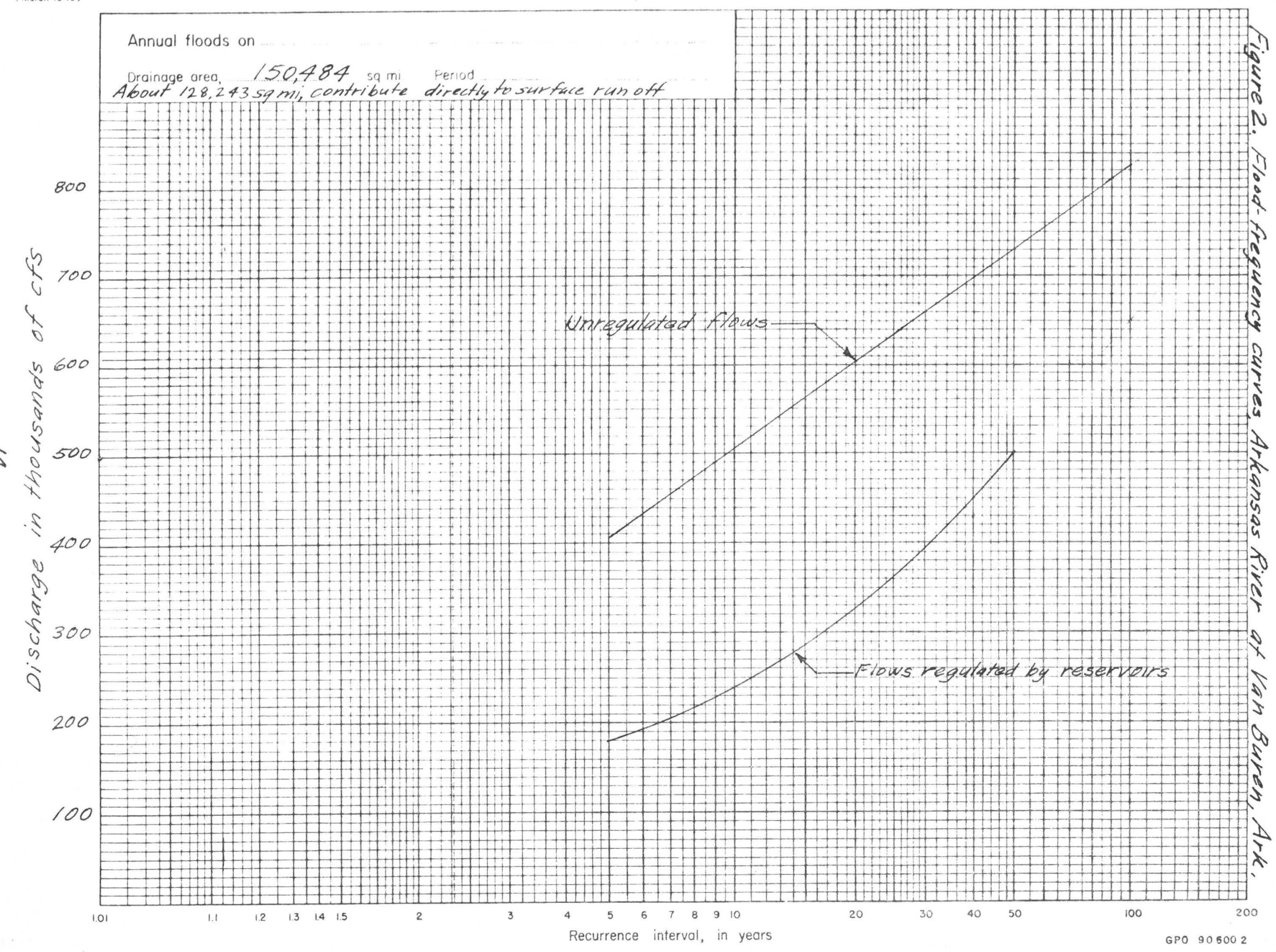


Figure 3. Relation of elevation to discharge Arkansas River at Van Buren, Ark.

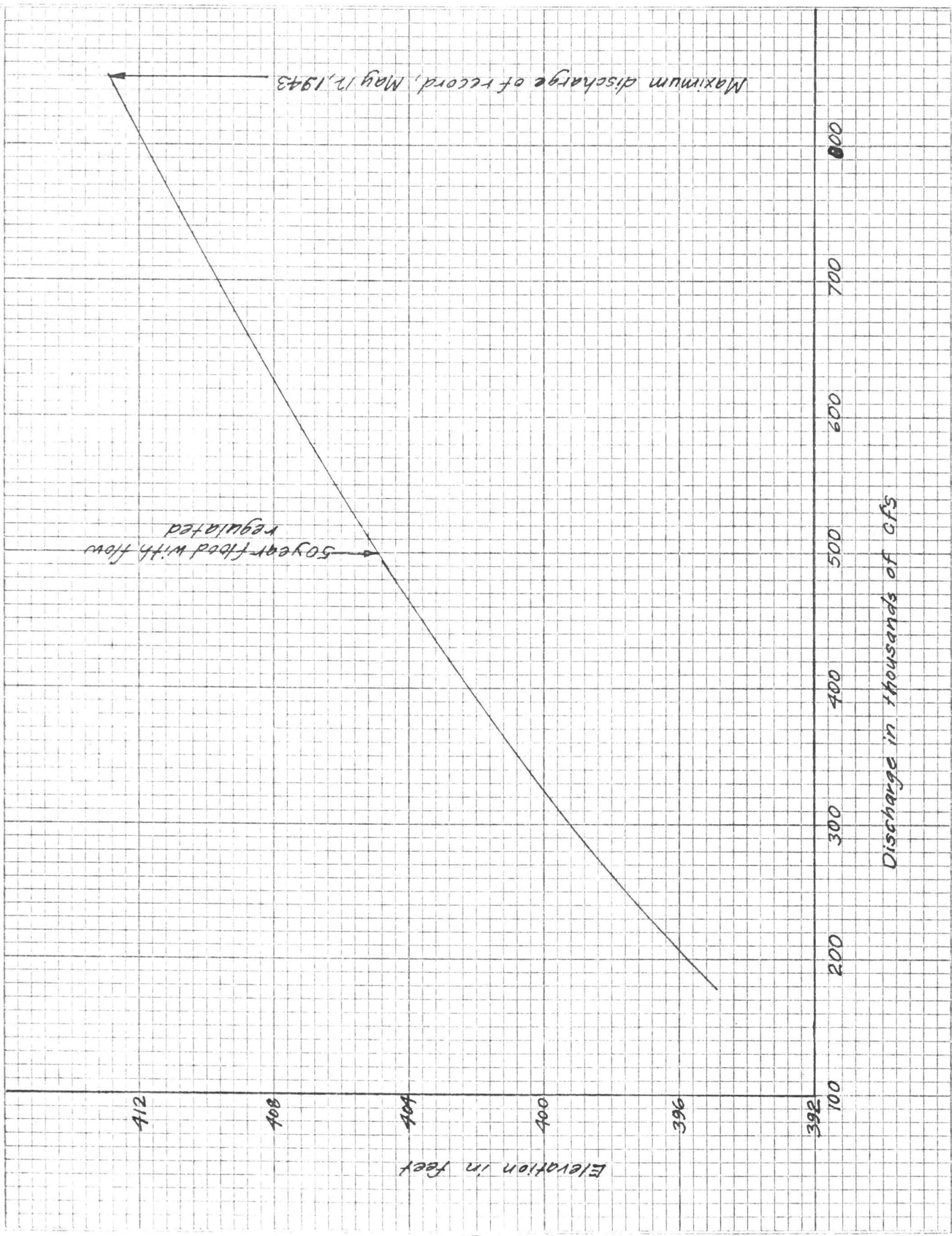


Figure 4.

Figure 4 Valley cross_section and flow distribution

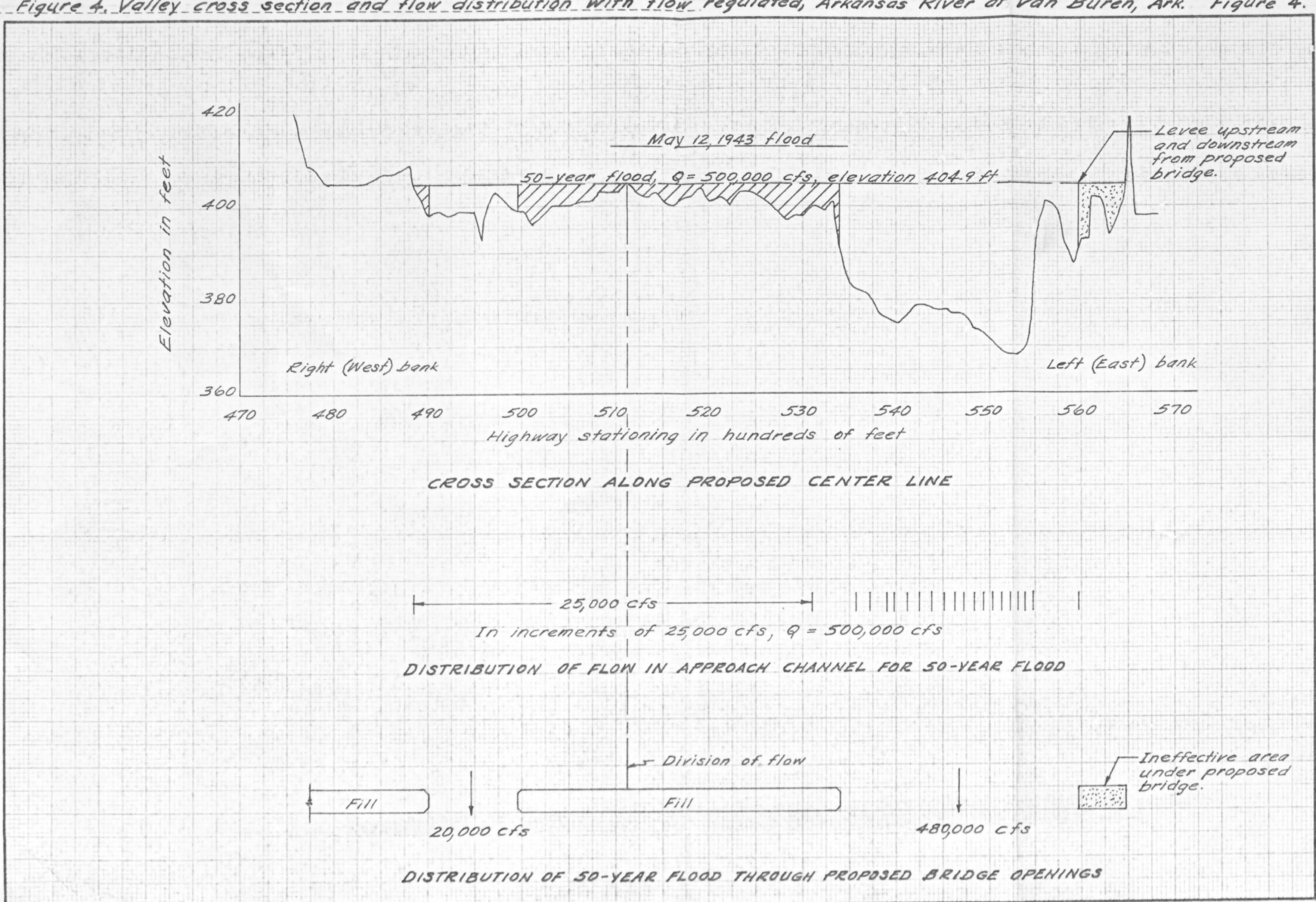


UNITED STATES DEPARTMENT OF THE INTERIOR

GEOLOGICAL SURVEY

File ......

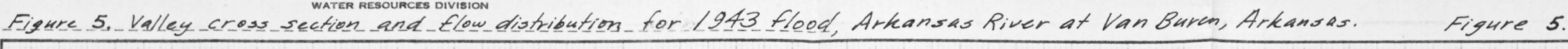

Figure 5. Valley_cross_section and_Elow_distribution for 1943 flood, Arkansas River at Van Burch, Arkansas. Figure 5.

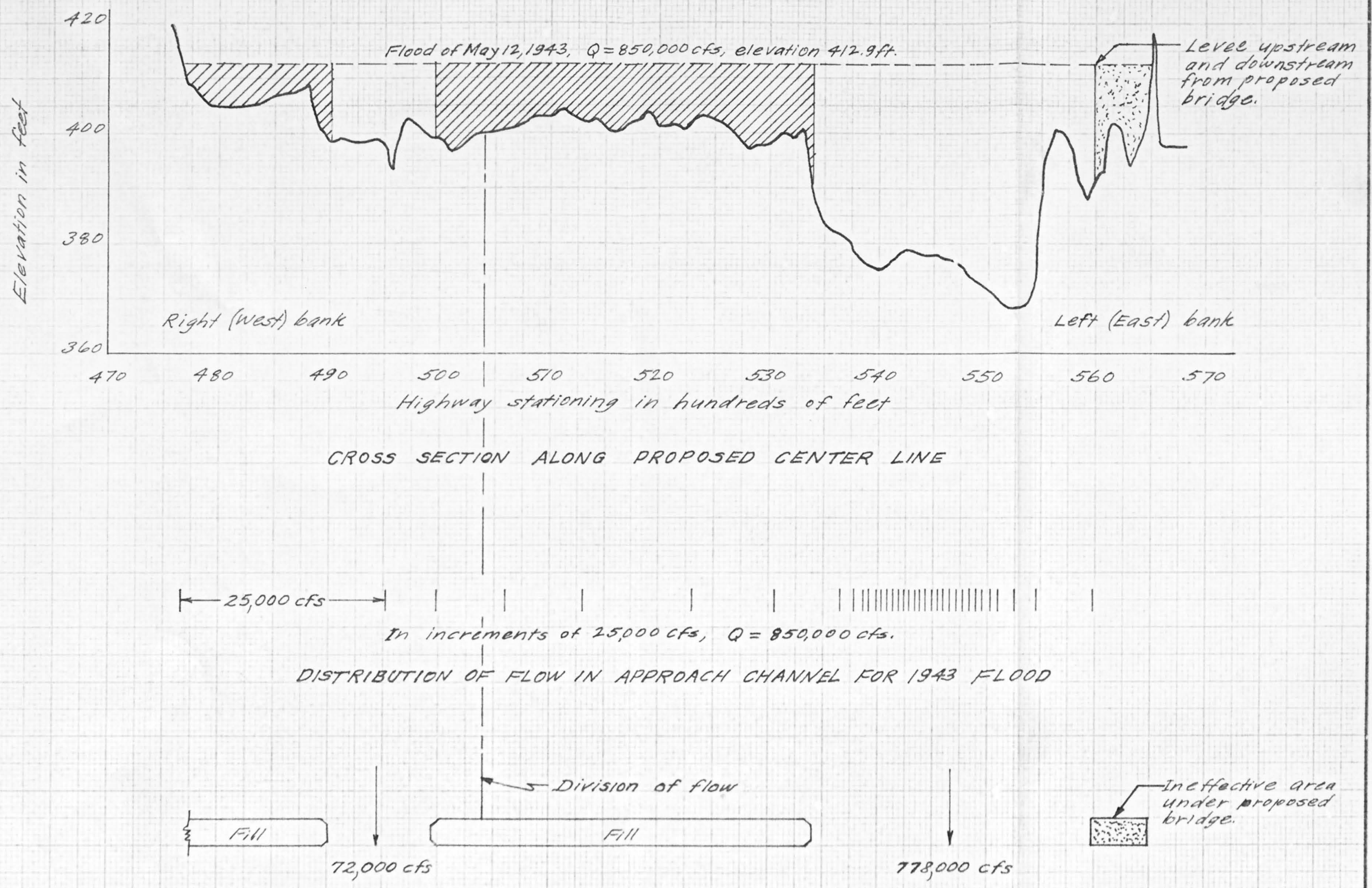

DISTRIBUTION OF 1943 FLOOD THROUGH PROPOSED BRIDGE OPENINGS

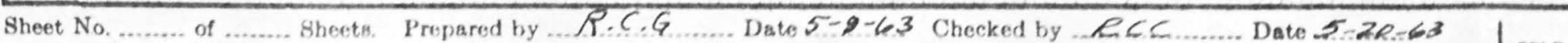


FLOODFLOW CHARACTERISTICS OF ARKANSAS RIVER

AT INTERSTATE HIGHWAY 540

AT VAN BUREN, ARKANSAS

\section{SUPPIEMENT I}

Introduction

After a detailed study of the report, "Floodflow Characteristics of Arkansas River at Interstate Highway 540, at Van Buren, Arkansas," the Arkansas H1ghway Department requested the Geological Survey to compute and show the distribution of flow in the approach channel and through the proposed bridge openings for a flood equal to the maximum flood of record modified by flood-control storage in reservoirs upstream from the bridge site.

This supplement contains the information relative to this additional request and becomes a part of the original report.

\section{Modified Maximum Flood of Record}

The Corps of Engineers has routed the maximum flood of record through the principal flood-control storage reservoirs on the Arkansas River and its tributaries as given in section, "History and Development." From this study, the maximum flood of record at the proposed highway crossing would be reduced from 850,000 cfs to about $550,000 \mathrm{cfs}$ (modified meximum flood of record). 
Recurrence Interval of Modified Flood

The recurrence interval of a flood event under natural conditions will most likely be changed when the flood is modified by storage in reservoirs. The effect of flood-control storage on the magnitude of a given flood depends greatly on its flood volume. High-magnitude floods with relatively small flood volumes would be reduced much more by flood-control storage than would similar floods with large flood volumes.

From the short extension of the frequency curve for flows regulated by reservoirs in figure 2, the recurrence interval for the modified maximum flood of record $(550,000 \mathrm{cfs})$ is about 63 years.

\section{Relation of Elevation to Discharge}

The relation of elevation to discharge is shown by the rating curve in figure 3. From this figure, the minimum elevation at which the discharge of 550,000 cfs would occur on the downstream side of the proposed road embankment is 406.2 feet.

\section{Distribution of Flow}

The water-surface elevation for the modified maximum flood of record and the proposed waterway openings are shown on the valley cross section along the proposed centerline in figure 6. The elevation of 406.2 feet represents the minimum stage at which a discharge of 550,000 cfs would occur under present channel conditions. 
The distribution of the modified flood $(550,000$ cfs at 406.2 feet) in the approach channel and through the proposed bridge openings is also shown in figure 6. The hydraulic data for the flow through the openings are presented in the following table:

\begin{tabular}{|c|c|c|c|}
\hline Bridge opening & Discharge & Area & Mean velocity \\
\hline Main channel & 524,000 cfs & $67,200 \mathrm{sq} \mathrm{ft}$ & $7.8 \mathrm{fps}$ \\
\hline Relief & 26,000 cfs & $6,100 \mathrm{sq}$ ft & $4.3 \mathrm{fps}$ \\
\hline
\end{tabular}

The division of flow will occur at about station $512+00$. 
Figure 6. Valley_ccess_section_and flow distribution fer modified maximum flood of record, Arkansas River at Van Buren, Ark.

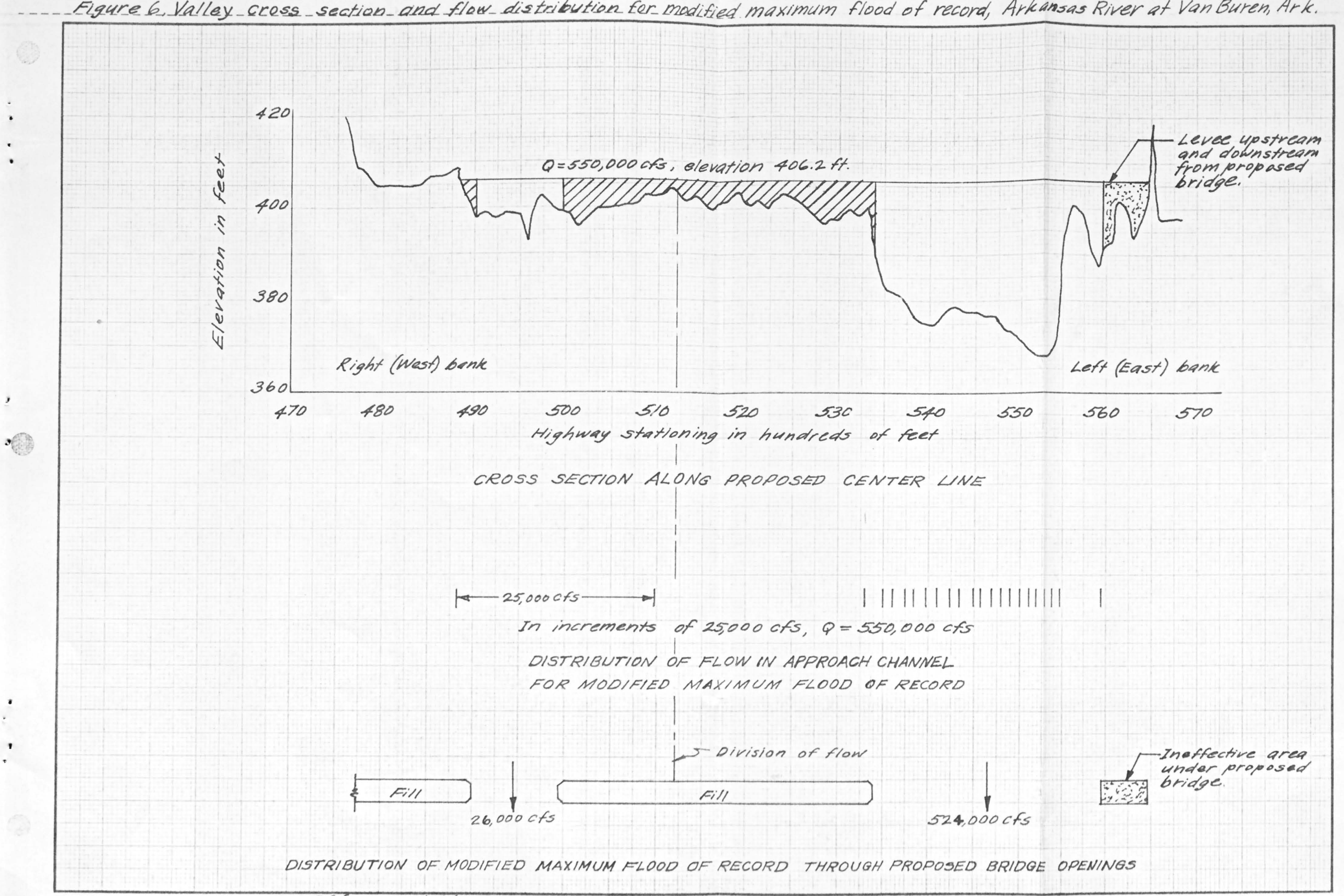




\section{FLOODFLOW CHARACTERISTICS OF ARKANSAS RIVER \\ AT INTERSTATE HIGHWAY 540 \\ AT VAN BUREN, ARKANSAS}

\section{SUPPLEMENT II}

\section{Introduction}

After further study of the original report and Supplement I, the Arkansas Highway Department revised the bridge openings in the Arkansas River crossing of Interstate Highway 540. The effective opening of the main-channel bridge was lengthened from 2,577 to 2,592 feet, and the relief bridge was reduced in length from 947 to 562 feet. Spur dikes were added to the right end of the main-channel bridge and to both ends of the relief bridge. The Ceological Survey was furnished with the revised bridge plans and requested to compute and show the distribution of flow in the approach channel and through the revised bridge openings for a flood equal to the maximum flood of record modified by flood-control storage in reservoirs upstream from the bridge site.

The supplement contains the information relative to this request and becomes a part of the original report.

\section{Distribution of Flow}

The distribution of flow shows the floodflow characteristics of the Arkansas River in the vicinity of the crossing with the bridge structures and embankment in place as they are to be constructed. 
The distribution of flow was computed for the modified maximum flood of record of 550,000 cfs. The definition of the modified. maximum flood of record, the recurrence interval of this flood, and the relation of elevation to discharge were explained in Supplement I.

The water-surface elevation and the waterway openings that are to be constructed are shown on the valley cross section along the proposed centerline in figure 7. The elevation of 406.2 feet represents the minimum stage at which a discharge of 550,000 cfs would occur under present channel conditions. The distribution of the modified flood in the approach channel and through the revised. bridge openings is also shown in figure 7. The hydraulic data for the flow through the openings are presented in the following table:

\begin{tabular}{|c|c|c|c|}
\hline Bridge opening & Discharge & Area & Mean velocity \\
\hline Main channel & 527,000 cfs & $67,400 \mathrm{sq}$ ft & $7.8 \mathrm{fps}$ \\
\hline Relief & $23,000 \mathrm{cfs}$ & $4,090 \mathrm{sq} f t$ & $5.6 \mathrm{fps}$ \\
\hline
\end{tabular}
Maximum Elevation of Water Surface above Constriction

The placement of the embankment and bridge across the Arkansas River valley will constrict the floodflow and cause a rise in the water surface on the upstream side of the constriction. The elevation of the water surface along the upstream side of the constriction outside of the drawdown zone is principally dependent upon: (1) the water-surface elevation at the downstream side of the embankment; (2) the normal friction loss between the beginning of the drawdown 
above the bridge opening and the downstream side of the embankment; and (3) the increase in elevation above the normal elevation in the unconstricted channel, which is known as backwater.

The difference in water-surface elevations from the downstream to the upstream side of the embankment will be about 1.3 feet. Therefore, the elevation of the water surface above the constriction with the revised bridge openings will be about 407.5 feet.

The stage-discharge relation at the site is unstable. As explained in the section, "Relation of Elevation to Discharge," the variation in elevation for a given discharge can be as much as 3 feet. Therefore, the elevations given for below and above the constriction could be as much as 3 feet higher. 


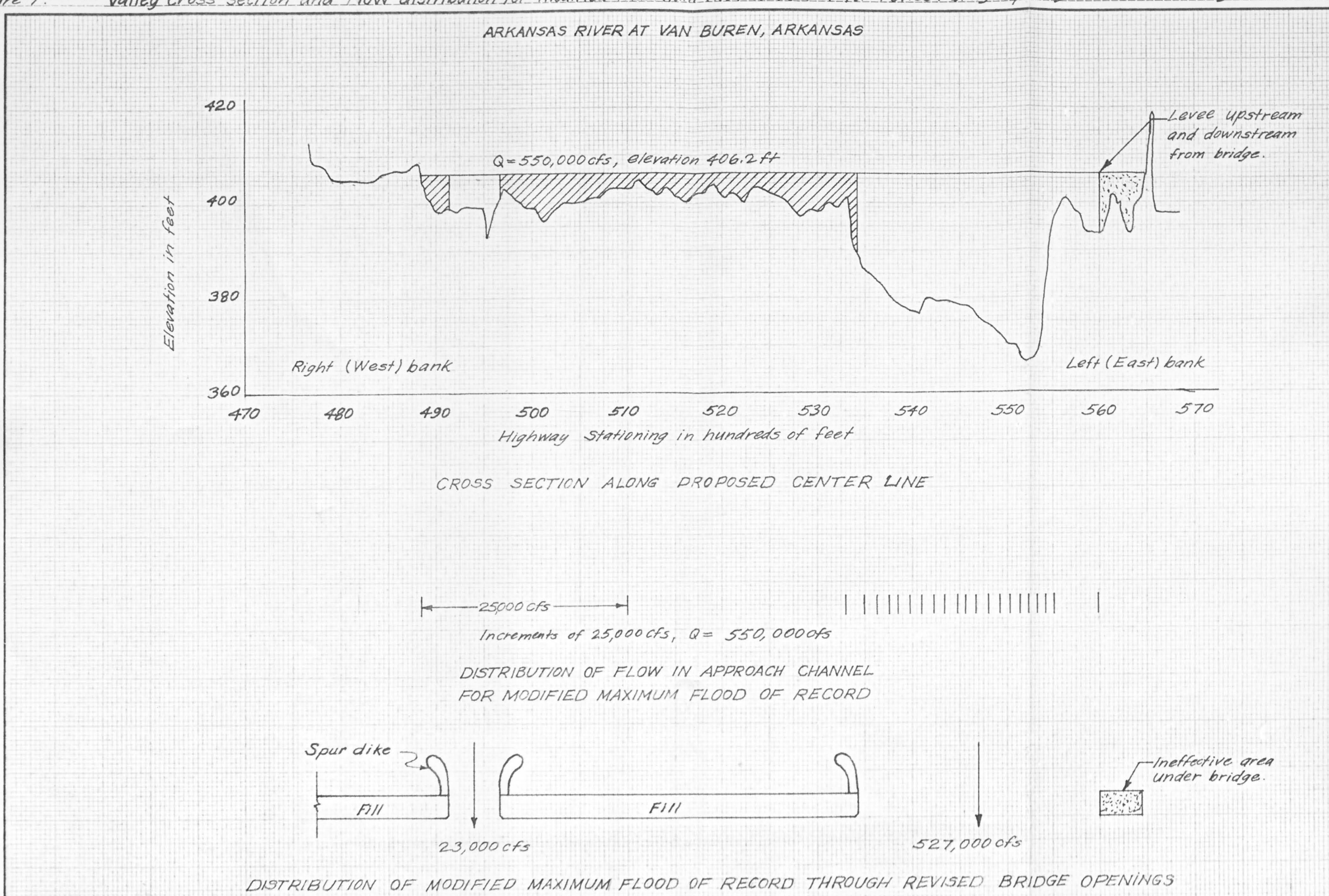

DISTRIBUTION OF MODIFIED MAXIMUM FLOOD OF RECORD THROUGH REVISED BRIDGE OPENINGS 